\title{
PENGGUNAAN METODE TRESHOLD GARCH DALAM MEMPREDIKSI HARGA SAHAM PT. GUDANG GARAM, Tbk.
}

\author{
Henry Winata \\ Yudith Dyah Hapsari \\ Universitas Katolik Indonesia Atmajaya \\ yudithd.hapsari@atmajaya.ac.id
}

\begin{abstract}
The cigarette industry in Indonesia continues to advance and evolve, it is supported by high demand by the public. PT. Gudang Garam, Tbk. is one of the companies that are already publicly traded in IDX (Indonesia Stock Exchange). The cigarette company's stock price tends to go up and make the tobacco companies have good potential in investing. This study uses time series analysis to forecast the stock price of PT. Gudang Garam, Tbk. Historical data is obtained from the stock price www. financeyahoo.com published by the Jakarta Stock Exchange. The results of this study indicate that the daily stock price data of PT. Gudang Garam, Tbk. during the period of 2010-2015 is the data that is contained heteroscedasticity and asymmetric shocks, so that we need the necessary variation model of ARCH / GARCH, Threshold GARCH (TGARCH) to produce accurate forecasting results. Results forecasting models indicate that the model TGARCH (1.1) is quite accurate in forecasting with a mean absolute percentage error of $4 \%$.
\end{abstract}

Keywords: Time Series, Forecasting, Heteroskedastis, Asymmetric, TGARCH

\section{PENDAHULUAN}

Perkembangan industri rokok di Indonesia saat ini sangat pesat, hal ini didukung dengan kemajuan teknologi pendukung industri rokok yang semakin modern. Potensi industri rokok di Indonesia sangat besar, hal ini disebabkan banyaknya jumlah perokok aktif sebagai konsumen utama industri ini. Menurut data WHO tahun 2008, Indonesia menempati peringkat ke-3 di dunia setelah Cina dan India sebagai Negara dengan tingkat konsumsi rokok tertinggi. Sebagai seorang investor yang tentu mau mengambil bagian dalam potensi ekonomi industri rokok tersebut, tentunya kita memerlukan analisis yang akurat dan dapat diandalkan untuk dijadikan dasar pengambilan keputusan investasi. Ada dua macam analisis dalam dunia investasi saham yaitu analisis fundamental dan analisis teknikal.

Analisis fundamental menyatakan bahwa setiap instrument investasi mempunyai landasan yang kuat yaitu nilai intrinsik yang dapat ditentukan melalui suatu analisis yang sangat hati-hati terhadap kondisi pada saat sekarang dan prospeknya dimasa yang akan datang. Ide dasar pendekatan ini adalah bahwa harga saham 
dipengaruhi oleh kinerja perusahaan. Analisis teknikal merupakan upaya untuk memperkirakan harga saham dengan mengamati perubahan harganya di waktu yang lalu. Jadi, obyek dari analisis teknikal ini adalah memprediksi dari suatu data time series dengan metode peramalan dan perhitungan yang akurat. Menurut Kodrat dan Indonanjaya (2010), diacu dalam Rizky Agusta (2015), Perubahan harga saham cenderung bergerak pada satu arah tertentu (trend). Pola tertentu pada masa yang lampau akan terulang kembali pada masa yang akan datang. Analisis teknikal lebih memperhatikan pada apa yang telah terjadi di pasar, daripada apa yang seharusnya terjadi. Para pelaku pasar modal di Bursa Efek Indonesia (BEI) menggunakan informasi tersebut untuk meraih keuntungan dari investasi mereka.

Kemampuan untuk memprediksi atau forecast merupakan salah satu teknik analisis yang bisa membantu para pelaku pasar modal untuk menentukan dasar pengambilan keputusan strategis yang bisa memberikan mereka keuntungan. Suatu pendugaan secara ilmiah terhadap masa depan akan jauh lebih berarti ketimbang pendugaan hanya mengandalkan intuisi saja.

Berbagai informasi situasional pada perekonomian maupun pasar saham yang ada pada saat sekarang ini mempengaruhi kestabilan harga saham yang menunjukkan asset investasi ini rentan terhadap gejolak. Keadaan dalam negeri maupun luar negeri turut berdampak kepada pasar saham di Indonesia. Pada periode tertentu, indeks saham barang konsumsi menunjukkan penurunan nilai dan sangat tidak stabil dengan volatilitas yang tinggi. Hal berbeda terjadi ketika perekonomian dalam keadaan baik dan iklim investasi sedang optimal khususnya pada saham sektor barang konsumsi, nilai indeks saham meningkat dan volatilitasnya cenederung stabil. Dari keadaan tersebut, terdapat kecenderungan adanya pola asimetris dari peningkatan volatilitas. Volatilitas yang tinggi cenderung terjadi saat terjadi guncangan negatif daripada saat terjadi guncangan yang bersifat positif.

Penelitian dengan data time series, terutama data keuangan seringkali memiliki volatilitas yang tinggi. Volatilitas mengacu pada kondisi berkonotasi tidak stabil, cenderung bervariasi dan sulit diperkirakan. Implikasi dari data yang bervolatilitas tinggi adalah variance error tidak bersifat konstan sehingga memiliki permasalahan heteroskedastis. Menggunakan permodelan regresi Ordinary Least Square pada penelitian mensyaratkan data bersifat homoskedastis dimana variance error tidak berubah-ubah agar estimator bersifat BLUE (Best Linear Unbiased Estimator). Adanya penyimpangan heteroskedastisitas pada data dimana variance error tidak bersifat konstan, maka dibutuhkan pemodelan lain yang tidak memandang heteroskedastisitas sebagai permasalahan, tetapi justru memanfaatkan kondisi tersebut untuk membuat permodelan. Karenanya akan digunakan permodelan $\mathrm{ARCH} /$ $G A R C H$ untuk memperoleh estimator yang efisien. (Nachrowi, 2006, diacu dalam Fitriani, 2009). Namun demikian Model ARCH/GARCH ini tidak selalu dapat menangkap adanya gejolak yang bersifat asimetris terhadap volatilitas (asymmetric shock). Untuk mengatasi hal ini, maka dapat digunakan suatu model yang merupakan perluasan dari model GARCH, yaitu model Treshold-GARCH (TGARCH).

\section{REVIEW LITERATUR DAN HIPOTESIS}

Penelitian dengan data time series sering kali menemukan kondisi dimana variance error tidak bersifat konstan sehingga memiliki permasalahan heteroskedastis. Menggunakan permodelan regresi Ordinary Least Square pada penelitian mensyaratkan data bersifat homoskedastis dimana variance error tidak berubah-ubah agar estimator bersifat BLUE 
(Best Linear Unbiased Estimator). Adanya penyimpangan heteroskedastisitas pada data dimana variance error tidak bersifat konstan, maka dibutuhkan pemodelan lain yang tidak memandang heteroskedastisitas sebagai permasalahan, tetapi justru memanfaatkan kondisi tersebut untuk membuat permodelan. Karenanya akan digunakan permodelan Autoregressive Conditional Heteroscedasticity (ARCH) dan Generalized Autoregressive Conditional Heteroscedasticity (GARCH) untuk memperoleh estimator yang efisien. (Nachrowi, 2006, diacu dalam Fitriani, 2009).

Menurut Winarno (2015, hal. 8.1), salah satu asumsi yang mendasari estimasi dengan model OLS (Ordinary Least Squares) adalah residual harus terbebas dari otokorelasi. Selain otokorelasi, asumsi lain yang sering digunakan adalah variabel pengganggu atau residual yang bersifat konstan dari waktu ke waktu. Apabila residual tidak bersifat konstan, maka terkandung masalah heteroskedastisitas. Untuk menghadapai masalah ini maka diciptakan model khusus untuk menghadapi kondisi seperti ini. Model tersebut dikenal dengan $\mathrm{ARCH}$.

ARCH (Autoregressive Conditional Heteroscedasticity) dikembangkan oleh Robert Engle (1982) dan dimodifikasi oleh Mills (1999). Dalam model ARCH, varian residual data runtut waktu tidak hanya dipengaruhi oleh variabel independent, tetapi juga dipengaruhi oleh nilai residual variabel yang diteliti. Menurut Widarjono (2007, hal. 327) GARCH (Generalized AutoRegressive Conditional Heteroscedasticity) merupakan penyempurnaan dari model $\mathrm{ARCH}$, model ini dikembangkan oleh Tim Bollerslev (1986 dan 1994). Bollerslev menyatakan bahwa varian residual tidak hanya tergantung dari residual periode lalu, tetapi juga varian residual periode lalu. Metode GARCH digunakan ketika terdapat variance error yang besarnya bergantung pada squared error terms pada beberapa tahun lalu. (Gujarati, 2003, hal. 862).
ARCH/GARCH merupakan suatu model peramalan/forecasting time series yang digunakan dalam single equation, artinya hanya menggunakan satu variabel saja. Dengan menggunakan informasi periode data yang lalu dapat meramal nilai data untuk periode yang akan datang. (Robin Sihombing, 2013). Model ini biasanya digunakan untuk mencari volatilitas suatu data. Yang dilihat dalam model ini adalah pengaruh varian dan eror kuadrat dari series datanya. ARCH/GARCH adalah kelanjutan dari peramalam model ARIMA, dimana syarat yang digunakan apabila model ARIMA yang dipilih tidak memenuhi asumsi homokedastisitas artinya modelnya masih mengandung heterokedastistas. Sehingga akan didapat beberapa model ARCH/ GARCH.

Eliyawati, Hidayat, dan Azizah (2014), menyatakan bahwa proses GARCH dapat ditafsirkan sebagai proses ARMA dalam $\mathrm{Xt}^{2}$. Prosedur umum dalam peramalan model GARCH sama dengan prosedur yang diterapkan pada model ARIMA, yaitu tahap identifikasi dengan membuat grafik harga saham terhadap waktu dan menghitung nilai return untuk melokalisasi pergerakan saham yang liar, tahap estimasi dan evaluasi, dan tahap aplikasi. Model GARCH (p,q) mengasumsikan bahwa variasi data fluktuasi dipengaruhi oleh sejumlah $p$ data fluktuasi sebelumnya dan sejumlah $\mathrm{q}$ data volatilitas sebelumnya, ide dibalik model ini seperti dalam model autoregresi biasa (AR) dan pergerakan rata-rata (MA), yaitu untuk melihat hubungan variabel acak dengan variabel acak sebelumnya. Setelah model didapat biasanya yang dipilih adalah model yang signifikan, error terkecil, bias proportion terkecil, korelasinya tinggi serta memenuhi asumsi normalitas dan homokedastisitas barulah model tersebut dapat digunakan untuk melakukan forecast/peramalan untuk nilai data periode berikutnya.

Sampai saat ini berbagai modifikasi dan pengembangan model ARCH/GARCH telah 
banyak dilakukan sehingga bentuknya sangat banyak. (Fryzlewicz et al, 2008; Bollerslev, 2008, diacu dalam Sumaryanto, 2009). Menurut Widarjono (2007, hal. 319), Variasi model ARCH/GARCH, antara lain:

a. $\mathrm{ARCH}$ in mean (ARCH-M)

Dalam banyak kasus terutama di pasar keuangan, adanya residual yang memiliki volatilitas tinggi seringkali mempengaruhi variabel dependen yang diamati. Dengan kata lain varian residual yang tidak konstan ini menjadi salah satu variabel independen di dalam persamaan rata-rata.

b. TGARCH (Treshold GARCH)

Pembahasan ARCH/GARCH sebelumnya berangkat dari asumsi bahwa terdapat gejolak yang bersifat simetris terhadap volatilitas (symmetric shocks to volatility). Tetapi dalam banyak kasus di sektor financial, misalnya di pasar ekuitas, terdapat sebuah gejolak yang bersifat asimetris (asymmetric shock). Artinya penurunan tajam di pasar (efek negatif) tidak serta merta akan diikuti dengan kenaikan di pasar (efek positif) dalam ukuran yang sama di waktu lain. Dengan kata lain efek negatif biasanya lebih besar dari efek positifnya.

c. EGARCH (Exponential GARCH)

Model Exponential General Auto Regressive Conditional Heteroscedastic (EGARCH) diperkenalkan oleh Daniel B. Nelson pada tahun 1991. Model ini merupakan pengembangan dari model GARCH. Kelebihan dari model EGARCH yaitu model ini mampu mengatasi varian yang tidak konstan. Selain itu, model ini juga bisa diterapkan untuk mengatasi adanya pengaruh asimetrik pada data, yaitu data yang memiliki nilai cross correlation antara residual kuadrat dan lag galatnya signifikan. Sedangkan metode GARCH tidak bisa diterapkan untuk data asimetrik. (Prasetyo dan Rahardjo, 2013).
Ahmad Sadeq (2008) meneliti Analisis Prediksi Indeks Harga Saham Gabungan Dengan Metode ARIMA (studi pada IHSG di Bursa Efek Jakarta). Data yang digunakan dalam penelitian ini merupakan data time series IHSG di BEJ selama satu tahun, yaitu mulai 2 Januari 2006 hingga 28 Desember 2006. Objek penelitian pengambilan data selama satu tahun (5 hari kerja) sebanyak 242 hari perdagangan. Penelitian ini menggunakan metode Autoregressive Integrated Moving Average (ARIMA). Hasil penelitiannya menemukan bahwa data IHSG periode 2 Januari 2006 - 28 Desember 2006 merupakan data runtut waktu (time series) yang bersifat tidak stasioner. Oleh karena itu dilakukan transformasi menggunakan proses pembedaan (differencing). Hasil empiris dari penelitian ini menunjukan bahwa peramalan IHSG dengan metode ARIMA untuk periode 2 Januari - 28 Desember 2006 terbukti akurat dengan tingkat kesalahan peramalan rata-rata sebesar $4,14 \%$.

Bayu Ariestya Ramadhan (2014), pada penelitian ini dilakukan analisis perbandingan performa model ARIMA dan model GARCH dalam melakukan peramalan harga saham perusahaan telekomunikasi yang terdaftar di BEI. Sampel yang digunakan adalah data harga saham PT. Telekomunikasi Indonesia Tbk., (TLKM), PT. Indosat Tbk., (ISAT), PT XL Axiata Tbk., (EXCL), dan PT Smartfren Telecom Tbk., (FREN). Data harga saham yang digunakan untuk mengestimasi model adalah harga saham yang diperdagangkan selama periode 1 Mei 2012 - 30 April 2013 yang diamati secara harian. Hasil analisis menemukan bahwa model yang cocok untuk memodelkan data harga saham TLKM adalah model ARIMA $(2,1,2)$ dan model $\operatorname{GARCH}(1,1)$. Untuk data harga saham ISAT, model yang cocok adalah model ARIMA $(0,1,14)$ dan $\operatorname{GARCH}(1,0)$. Untuk data harga harga saham EXCL, model yang cocok adalah model ARIMA $(1,1,1)$ dan model $\operatorname{GARCH}(1,0)$. Sedangkan untuk data harga saham FREN 
tidak dapat dimodelkan dengan menggunakan model ARIMA dan GARCH karena data harga saham FREN telah stasioner pada level serta memiliki varians yang konstan. Hasil penelitian menunjukkan bahwa model $\operatorname{ARIMA}(2,1,2)$ lebih superior dibandingkan model $\operatorname{GARCH}(1,1)$ dalam meramalkan harga saham TLKM, model $\operatorname{GARCH}(1,0)$ lebih superior dibandingkan model $\operatorname{ARIMA}(0,1,14)$ dalam meramalkan harga saham ISAT, dan model GARCH(1,0) lebih superior dibandingkan model $\operatorname{ARIMA}(1,1,1)$ dalam meramalkan harga saham EXCL.

Penelitian yang dilakukan oleh Lulik Presdita W (2012) dengan judul "APLIKASI MODEL ARCH-GARCH DALAM PERAMALAN TINGKAT INFLASI", data dalam penelitian ini menggunakan data closing price inflasi pada akhir bulan yang diperoleh dari Bank Indonesia periode Januari 2001 sampai Desember 2011.

Hasil penelitian menunjukan bahwa Data tingkat inflasi dimodelkan dengan metode ARIMA Box-Jenkins dan dideteksi terdapat adanya kasus heteroskedastisitas. Suatu kondisi dimana varian residual bersifat tidak konstan dinamakan heteroskedastisitas. Penerapan model ARCH-GARCH dalam penelitian ini ditujukan untuk mengatasi adanya heteroskedastisitas pada data tingkat inflasi. Dari analisis data yang dilakukan, didapatkan model ARIMA sebagai berikut : $\mathrm{Y}_{\mathrm{t}}=\mathrm{a}_{\mathrm{t}}+0,99851 \mathrm{Y}_{\mathrm{t}-1} \operatorname{dimana} \mathrm{Y}_{\mathrm{t}}=\sqrt{W t}$ $\sqrt{W t}$ dan $\mathrm{W}_{\mathrm{t}=} \sqrt{Z t} \sqrt{Z t}$ dengan $\sigma_{t}^{2} \sigma_{t}^{2}=0,0013305$ $+0,3169 a_{t-1}^{2} a_{t-1}^{2}$, dimana tingkat kepercayaan yang dipakai sebesar 95\%. Setelah dilakukan peramalan dengan menggunakan model $\mathrm{ARCH}$ (1) yang telah terbentuk, maka dapat diketahui ramalan tingkat inflasi untuk dua belas periode berikutnya pada tahun 2012. Hasil ramalan data tingkat inflasi terbesar adalah pada bulan Januari 2012 yaitu sebesar 4.73424, sedangkan hasil ramalan terkecil adalah pada bulan Desember 2012 yaitu sebesar 4.35817 .
Penelitian yang dilakukan oleh Gilang Paramitha, Waego Hadi Nugroho, dan Heni Kusdarwati dengan judul "Perbandingan Model Volatilitas Data Return dengan Menggunakan Model Exponentially Generalized Autoregressive Conditional Heteroscedasticity (EGARCH) $(1,1)$ dan Treshold Generalized Autoregressive Conditional Heteroscedasticity (TGARCH) $(1,1)$ ". Data yang digunakan adalah data retun IHSG 1 Juli 2002 sampai 12 Desember 2012 dan SSMI 9 November 1990 hingga 11 Januari 2012. Hasil dari penelitian ini adalah bahwa model EGARCH(1,1) dan TGARCH $(1,1)$ sama baiknya untuk memodelkan dan melihat efek asimetris pada volatilitas data return IHSG maupun SSMI.

Penelitian yang dilakukan oleh Ratna Satari Janah dengan judul "ANALISIS VOLATILITAS RETURN HARGA MINYAK KELAPA SAWIT DI PASAR INTERNASIONAL", dalam penelitian ini model analisis yang digunakan dalam penelitian ini adalah Model Autoregressive (AR) yang diproses dengan menggunakan Exponential Generalized Autoregressive Conditional Heteroskedastic (EGARCH). Keunggulan model ini adalah selain dapat mengetahui ada tidaknya time varying volatility, juga leverage effect yang terdapat dalam data return harga minyak kelapa sawit internasional. Hasil penelitian menunjukkan bahwa return harga minyak mentah berpengaruh positif dan signifikan terhadap return harga minyak kelapa sawit.

Berdasarkan beberapa tinjauan pustaka diatas, penulis ingin mengetahui apakah model ARIMA atau model ARCH/GARCH yang lebih baik dalam memprediksi harga saham PT. Gudang Garam, Tbk. disertai dengan pengukuran peramalan untuk mengetahui akurasi dari model ARIMA atau model ARCH/GARCH tersebut. 


\section{METODE PENELITIAN}

\section{Definisi Operasional Variabel}

Variabel Terikat (Dependent)

Dalam penelitian ini variabel terikat yang digunakan adalah proyeksi harga saham PT. Gudang Garam, Tbk. dalam periode peramalan 1 bulan. $Y_{t}=$ Harga saham yang akan diramal pada waktu ke-t (dijadikan sebagai variabel dependen) Variabel Bebas (Independent)

Penelitian ini akan menggunakan metode time series, sehingga akan mengabaikan variabel independen sama sekali, karena menggunakan nilai sekarang dan nilai-nilai lampau untuk menghasilkan peramalan jangka pendek yang akurat. Oleh sebab itu variabel bebas pada model ini akan dinyatakan dalam:

$\mathrm{Y}_{\mathrm{t}-1}=$ Harga saham 1 hari sebelum $\mathrm{t}$ (dijadikan sebagai variabel independen)

$\mathrm{Y}_{\mathrm{t}-2}=$ Harga saham 2 hari sebelum $\mathrm{t}$ (dijadikan sebagai variabel independen)

$\mathrm{Y}_{\mathrm{t}-\mathrm{n}}=$ Harga saham $\mathrm{n}$ hari sebelum $\mathrm{t}$ (dijadikan sebagai variabel independen)

\section{Metode Pengumpulan Data}

Jenis Data dan Sumber Data

Data yang digunakan untuk penulisan ini adalah data kuantitatif, data diperoleh dari harga saham harian (5 hari per minggu) PT. Gudang Garam, Tbk. Harga saham yang dipakai adalah harga saham penyesuaian akhir (Adjusted Close) periode tahun 2010 - 2015. Data mengenai harga saham PT. Gudang Garam, Tbk. diperoleh di website (http://finance.yahoo.com).

\section{Teknik Pengumpulan Data}

Metode pengumpulan data yang akan digunakan dalam penelitian ini adalah:

1. Ditinjau dari waktu pengumpulannya, data yang digunakan dalam bentuk time series. Untuk data yang digunakan dalam penelitian ini dalam interval waktu harian.
2. Ditinjau dari sifatnya, data yang digunakan adalah data kuantitatif karena penulis menggunakan data harga saham harian PT. Gudang Garam, Tbk. periode 2010 - 2015.

3. Ditinjau dari sumbernya, data yang digunakan adalah data internal karena data tersebut memberikan gambaran mengenai keadaan PT. Gudang Garam, Tbk. periode tahun 2010 $-2015$.

4. Data harga saham harian (5 hari per minggu) PT. Gudang Garam, Tbk. periode tahun 2010 - 2015 diperoleh melalui http://finance. yahoo.com.

\section{Metode Analisis Data}

Metode analisis yang digunakan untuk mencapai tujuan pada penelitian kali ini adalah dengan analisis deskriptif dan analisis time series untuk memprediksi harga saham PT. Gudang Garam, Tbk. menggunakan software Microsof Excel 2007 dan E-Views 6.0.

\section{Analisis Time Series}

Analisis yang terlebih dahulu dilakukan ialah Uji Normalitas Jarque-Bera dan Uji ARCHLM (Lagrange Multiplier). Uji ARCH-LM dilakukan untukmenguji apakah data mengandung sifat heteroskedastisitas atau tidak, jika data time series mengandung heteroskedastisitas, maka dilanjutkan dengan metode $\mathrm{ARCH} / \mathrm{GARCH}$ untuk meramalkan harga saham PT. Gudang Garam, Tbk.

\section{Uji Normalitas Jarque-Bera}

Salah satu asumsi dalam analisis statistika adalah data berdistribusi normal. Uji normalitas digunakan untuk melihat apakah data harga saham PT. Gudang Garam, Tbk. periode 2010-2015 mempunyai distribusi (sebaran) yang normal atau tidak. Dalam aplikasinya nilai Jarque-Bera (JB) dibandingkan dengan nilai Chi-Square Tabel pada derajat kebebasan 2. (Winarno, 2015, hal. 5.41-5.43). Uji Jarque-Bera yang digunakan pada penelitian ini dengan menggunakan $\alpha=5 \%$, 
hipotesis yang digunakan sebagai berikut:

$\mathrm{H}_{0}$ : Data Return berdistribusi normal

$\mathrm{H}_{\mathrm{a}}$ : Data Return tidak berdistribusi normal

- Bila nilai (JB) tidak signifikan (lebih kecil dari 2), maka data berdistribusi normal.

- Bila probabilitas lebih besar dari $\alpha=5 \%$, maka data berdistribusi normal (hipotesis nolnya adalah data berdistribusi normal).

ARCH-LM (Lagrange Multiplier) Test

Uji ini digunakan untuk menguji efek ARCH data. Pengujian ini ditujukan apakah kita bisa menggunakan model ARCH/GARCH atau model ARIMA saja. Hipotesis uji efek ARCH adalah sebagai berikut:

$\mathrm{H}_{0}$ : data tidak mengandung unsur $\mathrm{ARCH}$ (homoskedastis)

$\mathrm{H}_{\mathrm{a}}$ : data mengandung unsur $\mathrm{ARCH}$ (heteroskedastis)

Jika nilai hitung $\chi^{2}$ yakni $\operatorname{Prob}\left(\mathrm{Obs}^{*} \mathrm{R}^{2}\right)$ lebih rendah dibandingkan dengan tingkat signifikansi $5 \%$ atau 0,05 , maka kita dapat menolak $\mathrm{H}_{0}$ dan menyimpulkan bahwa dalam data terdapat unsur heteroskedastisitas. Bila memang terdapat unsur $\mathrm{ARCH}$ pada data, maka peramalan dilakukan menggunakan metode $\mathrm{ARCH} /$ GARCH. Adanya unsur ARCH ditandai dengan ditolaknya $\mathrm{H}_{0}$ dan simpulkan bahwa data bersifat heteroskedastis. Hal ini berarti permasalahan heteroskedastis tidak dapat diatasi dengan pemodelan ARIMA saja, harus menggunakan model ARCH/GARCH. Pengujian efek ARCH dilakukan sebelum pemodelan ARCH/GARCH dan setelah pemodelan ARCH/GARCH.

\section{Autoregressive Conditional Heteroscedasticity / Generalized Autoregressive Conditional Heteroscedasticity}

Dalam melakukan Estimasi Model $\mathrm{ARCH} / \mathrm{GARCH}$ terdiri dari beberapa langkah, sebagai berikut: a. Estimasi Model

Setelah menetapkan model sementara dari hasil identifikasi, langkah berikutnya adalah melakukan estimasi paramater autoregressive dan moving average yang tercakup dalam model untuk melihat kembali apakah model yang dibuat sudah memenuhi syarat atau belum. (Firmansyah, 2000, diacu dalam Suhartono, 2011).

Menurut Winarno (2015, hal. 8.22), Ada beberapa cara yang dapat digunakan untuk memilih model terbaik, yaitu:

- Melihat nilai $\mathrm{R}^{2}$. Model yang paling tinggi nilai $\mathrm{R}^{2}$-nya berarti model paling baik, karena dapat menjelaskan hubungan antara variabel independen dengan variabel dependen lebih baik dibanding model lain yang $\mathrm{R}^{2}$-nya lebih rendah.

- Melihat koefisien AIC (Akaike Info Criterion) dan SIC (Schwarz Criterion). Model yang paling rendah nilai AIC dan SIC-nya adalah model yang paling baik.

b. Evaluasi Model

Setelah didapat model ARCH/ GARCH maka dilakukan uji ARCH-LM (Lagrange Multiplier). Berbeda dengan uji yang sebelumnya, kali ini uji ARCHLM digunakan untuk melihat apakah model ARCH/GARCH yang dibentuk sudah dapat mengatasi heteroskedastisitas. Pada uji ARCH-LM yang kedua ini kita mengharapkan gagal tolak $\mathrm{H}_{0}$ yaitu residu dari model GARCH bersifat homoskedastis. Jika masalah heteroskedastisitas sudah dapat diatasi, maka model ARCH/GARCH dapat digunakan untuk meramalkan harga saham PT. Gudang Garam, Tbk.

c. Peramalan

Jika model terbaik telah ditetapkan, maka model siap digunakan untuk peramalan. Ada beberapa metode yang digunakan untuk menunjukan kesalahan yang disebabkan oleh suatu teknik peramalan tertentu. Hampir 
semua ukuran tersebut menggunakan beberapa fungsi dari perbedaan antara nilai sebenarnya dengan nilai peramalannya. Perbedaan nilai sebenarnya dengan nilai peramalan ini biasanya disebut sebagai residual.

Menurut Arsyad (1995, diacu dalam Sadeq, 2008) ada beberapa teknik untuk mengevaluasi hasil peramalan, diantaranya:

i. Mean Absolute Deviation (MAD) atau simpangan absolut rata-rata

$$
\mathrm{MAD}=\frac{\sum_{t-1}^{n}\left(Y_{t}-\hat{Y}_{t}\right)}{n}
$$

ii. Mean Squared Error (MSE) atau Kesalahan rata-rata kuadrat

$$
\text { MSE }=\frac{\sum_{t-1}^{n}\left(Y_{t}-\hat{Y}_{t}\right)^{2}}{n}
$$

iii. Mean Absolute Percentage Error (MAPE) atau persentase kesalahan absolut rata-rata

$$
\text { MAPE }=\frac{\sum_{t=1}^{n} \frac{I Y_{t}-\hat{Y}_{t} I}{Y_{t}}}{n}
$$

iv. Mean Percentage Error (MPE) atau Persentase kesalahan rata-rata

$$
\mathrm{MPE}=\sum_{t=1}^{n} \frac{\left(Y_{t}-\hat{Y}\right)_{t}}{n}
$$

\section{Model Treshold Generalized Autoregressive Conditional Heteroscedasticity (TGARCH)}

Asumsi model ARCH/GARCH adalah terdapat guncangan (shock) yang bersifat simetris terhadap volatilitas. Namun terkadang dalam pasar saham ditemukan bahwa volatilitas dari error ketika ada guncangan negatif lebih besar daripada guncangan positif. Kasus ini disebut sebagai guncangan asimetris (Asymetric shock) dimana penurunan tajam (efek negatif) tidak serta merta akan diikuti dengan kenaikan (efek positif) dalam ukuran yang sama pada periode berikutnya. Model TGARCH (Treshold Generalized Autoregressive Conditional Heteroscedasticity) adalah salah satu model yang dapat mengatasi guncangan asimetris tersebut.

Model TGARCH diperkenalkan oleh Zakoian (1990) dan Glosten, Jaganathan dan Runkle (1993). Persamaan model TGARCH secara umum adalah sebagai berikut.

$$
\begin{aligned}
& \text { Return }_{\mathrm{t}}=\beta_{0}+\beta_{\mathrm{t}} \mathrm{X}_{\mathrm{t}}+\mathrm{e}_{\mathrm{t}} \\
& \sigma_{\mathrm{t}}^{2}=\alpha_{0}+\alpha_{1} \varepsilon_{\mathrm{t}-1}^{2}+\ldots+\alpha_{\mathrm{p}} \varepsilon_{\mathrm{t}-\mathrm{p}}^{2}+\phi \varepsilon_{\mathrm{t}-1}^{2} d_{\mathrm{t}-1}+
\end{aligned}
$$$$
\lambda_{\mathrm{t}} \sigma_{\mathrm{t}-1}^{2}+\ldots+\lambda_{\mathrm{q}} \sigma_{\mathrm{t}-\mathrm{q}}^{2}
$$

dimana $d$ adalah peubah boneka (dummy variable),

$d_{\mathrm{t}-1}=1$ jika $\varepsilon_{\mathrm{t}-1}<0$ dan $d_{\mathrm{t}-1}=0$ jika $\varepsilon_{\mathrm{t}-1}>0$.

Setelah didapat model TGARCH maka dilakukan uji ARCH-LM (Lagrange Multiplier). Berbeda dengan uji yang sebelumnya, kali ini uji ARCH-LM digunakan untuk melihat apakah model TGARCH yang dibentuk sudah dapat mengatasi heteroskedastisitas.

Hipotesis ARCH-LM sebagai berikut:

$\mathrm{H}_{0}$ : residu bersifat homoskedastis

$\mathrm{H}_{\mathrm{a}}$ : residu bersifat heteroskedastis

Pada uji ARCH-LM yang kedua ini kita mengharapkan gagal tolak $\mathrm{H}_{0}$ yaitu residu dari model TGARCH bersifat homoskedastis. Jika masalah heteroskedastisitas sudah dapat diatasi, maka model TGARCH dapat digunakan untuk meramalkan harga saham PT. Gudang Garam, Tbk.

\section{HASIL PENELITIAN DAN PEMBAHASAN}

Analisis time series pada penelitian ini dilakukan dengan menggunakan metode $\mathrm{ARCH} /$ GARCH. Sebelum dilakukan analisis time series menggunakan ARCH/GARCH, terlebih dahulu dilakukan uji ARCH-LM (Lagrange Multiplier) dan Uji Normalitas Jarque-Bera. 


\section{Gambar 1}

Grafik Pergerakan Harga Saham Harian PT.

Gudang Garam, Tbk.

Periode Tahun 2010 - 2015

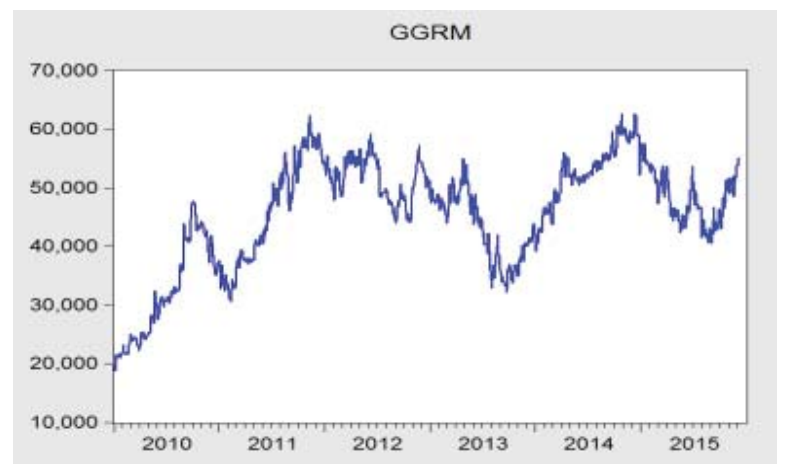

Sumber: data olahan E-Views 6

Pada Gambar 4.1 dapat dilihat data pergerakan harga saham PT. Gudang Garam, Tbk. yang menunjukan terjadi pola trend naik dan trend turun yang memiliki variansi yang cukup tinggi. Hal ini menunjukan data memiliki volatilitas yang sangat tinggi sehingga dapat bersifat hetereoskedastis dan memiliki gejolak asimetrik.

\section{Uji ARCH-LM}

Tabel 1

\section{Uji ARCH-LM}

Heteroskedasticity Test: ARCH

\begin{tabular}{llll}
\hline \hline F-statistic & 98167.04 & Prob. F(1,1546) & 0.0000 \\
Obs*R-squared & 1523.999 & Prob. Chi-Square(1) & 0.0000 \\
\hline \hline
\end{tabular}

Sumber: data olahan E-Views 6

Dari hasil uji ARCH-LM tersebut, terlihat nilai Prob $\left(\mathrm{Obs}^{*} \mathrm{R}^{2}\right)$ adalah 0,0000, jika dibandingkan dengan tingkat signifikansi 5\% atau 0,05, maka kita dapat menolak $\mathrm{H}_{0}$ dan simpulkan bahwa terdapat heteroskedastisitas pada data. Untuk mengatasi permasalahan tersebut, Analisis time series harus dilakukan dalam Metode ARCH/ GARCH. Dengan menggunakan ARCH/GARCH, estimasi menggunakan Maximum likelihood tidak seperti ARIMA yang menggunakan OLS.

\section{Uji Normalitas Jarque-Bera}

Uji normalitas pada model regresi digunakan untuk menguji apakah nilai residual yang dihasilkan dari regresi terdistribusi secara normal atau tidak. Model regresi yang baik adalah yang memiliki nilai residual yang terdistribusi secara normal.

Gambar 2

Uji Normalitas

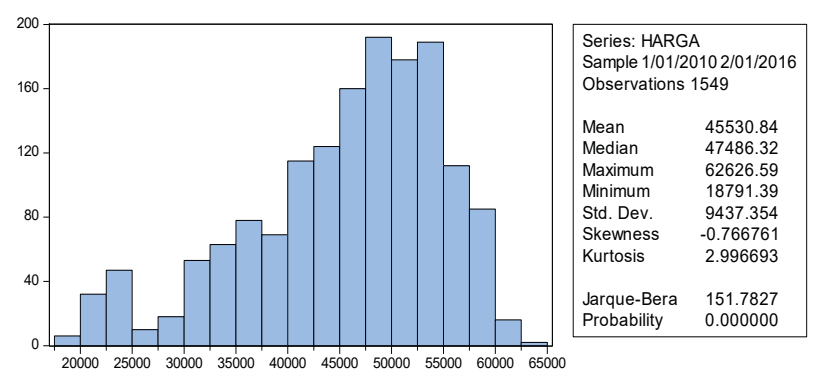

Sumber: data olahan E-Views 6

Berdasarkan gambar, terlihat bahwa nilai J-B signifikan (lebih besar dari 2), maka data berdistribusi normal. Prob. $<\alpha=0,0000<0,05$ maka tolak $\mathrm{H}_{0}$ yang berarti data residual tidak berdistribusi normal.

Pemodelan menggunakan TresholdGARCH dikarenakan jika menggunakan model ARIMA, residualnya bersifat heteroskedastis, yaitu variansnya tidak konstan antar waktu. Dengan menggunakan Treshold-GARCH, estimasi menggunakan Maximum likelihood tidak seperti ARIMA yang menggunakan OLS. Pada estimasi pemodelan harga saham PT. Gudang Garam, Tbk. menggunakan Model TGARCH $(1,1)$ didapat hasil sebagai berikut: 
Tabel 2

Hasil Analisis TGARCH $(1,1)$

Dependent Variable: HARGA

Method: ML - ARCH (Marquardt) - Normal distribution

Date: 02/15/16 Time: 18:11

Sample (adjusted): 1/08/2010 12/31/2015

Included observations: 1544 after adjustments

Convergence achieved after 69 iterations

Presample variance: backcast (parameter $=0.7$ )

$\mathrm{GARCH}=\mathrm{C}(3)+\mathrm{C}(4) * \operatorname{RESID}(-1)^{\wedge} 2+\mathrm{C}(5) * \operatorname{RESID}(-$

$1)^{\wedge} 2 *(\operatorname{RESID}(-1)<0)+$

$\mathrm{C}(6) * \mathrm{GARCH}(-1)$

\begin{tabular}{|c|c|c|c|c|}
\hline Variable & Coefficient & Std. Error & z-Statistic & Prob. \\
\hline $\mathrm{C}$ & -103728.6 & 1063692. & -0.097517 & 0.9223 \\
\hline $\mathrm{AR}(5)$ & 1.000989 & 0.006946 & 144.1104 & 0.0000 \\
\hline \multicolumn{5}{|c|}{ Variance Equation } \\
\hline C & 14837018 & 801847.5 & 18.50354 & 0.0000 \\
\hline $\operatorname{RESID}(-1)^{\wedge} 2$ & 0.082291 & 0.009746 & 8.443727 & 0.0000 \\
\hline & 0.199653 & 0.025458 & 7.842397 & 0.0000 \\
\hline GARCH $(-1)$ & -0.984768 & 0.002508 & -392.6853 & 0.0000 \\
\hline R-squared & 0.948758 & \multicolumn{2}{|c|}{ Mean dependent var } & 45615.80 \\
\hline Adjusted R-squared & 0.948592 & \multicolumn{2}{|c|}{ S.D. dependent var } & 9333.502 \\
\hline S.E. of regression & 2116.220 & \multicolumn{2}{|c|}{ Akaike info criterion } & 18.23130 \\
\hline Sum squared resid & $6.89 \mathrm{E}+09$ & \multicolumn{2}{|c|}{ Schwarz criterion } & 18.25206 \\
\hline Log likelihood & -14068.57 & \multicolumn{2}{|c|}{ Hannan-Quinn criter. } & 18.23903 \\
\hline F-statistic & 5695.332 & \multicolumn{2}{|c|}{ Durbin-Watson stat } & 0.449383 \\
\hline Prob(F-statistic) & 0.000000 & & & \\
\hline \multirow[t]{3}{*}{ Inverted AR Roots } & 1.00 & \multirow[t]{2}{*}{$.31-.95 \mathrm{i}$} & \multirow[t]{2}{*}{$.31+.95 \mathrm{i}$} & \multirow[t]{2}{*}{$-.81-.59 \mathrm{i}$} \\
\hline & $-.81+.59 \mathrm{i}$ & & & \\
\hline & Estimated AR $\mathrm{p}$ & rocess is nonstation & onary & \\
\hline
\end{tabular}

Sumber: data olahan E-Views 6

Conditional Mean Equation

$\operatorname{harga}_{(\mathrm{t})}=-103728,6+1,000989 \operatorname{harga}_{(\mathrm{t}-5)} * *+\mathrm{e}_{\mathrm{t}}$

Conditional Variance Equation

$\sigma^{2}=14837018+0.082291 \varepsilon_{t-1}^{2}+0.199653 \varepsilon^{2}{ }_{t}$

${ }_{1} d_{\mathrm{t}-1}{ }^{* *}-\mathbf{0 . 9 8 4 7 6 8} \sigma_{\mathrm{t}-1}^{2} * *$ Keterangan: ** Signifikan pada taraf $5 \%$
Hasil estimasi tersebut merupakan model yang didapat melihat AIC dan SIC yang lebih kecil daripada ordo-ordo ARMA lainnya. Model tersebut menjelaskan pada taraf signifikansi 5\% nilai harga saham ke-t dipengaruhi oleh nilai harga saham pada 5 lag sebelumnya. Hal ini menunjukkan bahwa harga saham secara langsung dipengaruhi oleh guncangan atau shock pada periode sebelumnya.

Sedangkan volatilitas harga saham yang digambarkan oleh varians ke-t pada taraf signifikansi $5 \%$ dipengaruhi oleh varians 1 hari sebelumnya, dan dipengaruhi residual varian sebelumnya. Hal ini menunjukkan bahwa jika volatilitas kemarin meningkat, maka volatilitas hari ini juga ikut meningkat. Nilai 0,199653 menunjukkan terjadi gejolak asimetris dalam model yang menggambarkan dampak bad news dalam harga saham berbeda dengan dampak yang ditimbulkan oleh good news.

Selanjutnya gunakan uji ARCHLM untuk mengetahui apakah residualnya homoskedastis atau tidak. Setelah dilakukan uji heteroskedastisitas didapat hasil sebagai berikut:

Tabel 3

Uji ARCH-LM

Heteroskedasticity Test: ARCH

\begin{tabular}{llll}
\hline \hline & & & \\
F-statistic & 0.372598 & Prob. F(1,1542) & 0.5417 \\
Obs*R-squared & 0.372991 & Prob. Chi-Square(1) & 0.5414 \\
\hline \hline
\end{tabular}

Sumber: data olahan E-Views 6

Dari hasil tersebut dapat dilihat bahwa pada taraf signifikansi 5\% tidak terdapat masalah heteroskedastisitas yang berartibahwaresidualnya bersifat homoskedastis. Homoskedastis berarti bahwa variansnya konstan antar waktu dan menandakan model bisa digunakan untuk memodelkan harga saham. Tahap selanjutnya ialah proyeksi harga saham menggunakan model yang telah dipilih, yaitu model TGARCH( 1,1$)$. Pengukuran Kesalahan Peramalan 
Tabel 4

Perhitungan Evaluasi Hasil Peramalan

\begin{tabular}{|c|c|c|c|c|c|c|c|}
\hline tanggal & $\begin{array}{c}\text { harga } \\
\text { saham } \\
\text { aktual } \\
\text { Yt }\end{array}$ & $\begin{array}{c}\text { harga } \\
\text { peramalan } \\
\text { (Y) }\end{array}$ & $\begin{array}{c}\text { error } \\
(\mathbf{E t})\end{array}$ & |Et $\mid$ & Et2 & $\mid \mathbf{E t} / \mathbf{Y t}$ & $\mathbf{E} t / \mathbf{Y t}$ \\
\hline 04/01/2016 & 53725 & 55055,86 & $-1330,86$ & 1330,86 & 1771188,34 & 0,0248 & $-0,0248$ \\
\hline 05/01/2016 & 53400 & 54731,53 & $-1331,53$ & 1331,53 & 1772972,14 & 0,0249 & $-0,0249$ \\
\hline 06/01/2016 & 54750 & 55156,95 & $-406,95$ & 406,95 & 165608,30 & 0,0074 & $-0,0074$ \\
\hline 07/01/2016 & 54025 & 55156,95 & $-1131,95$ & 1131,95 & 1281310,80 & 0,0210 & $-0,0210$ \\
\hline 08/01/2016 & 55100 & 54036,54 & 1063,46 & 1063,46 & 1130947,17 & 0,0193 & 0,0193 \\
\hline 11/01/2016 & 54500 & 54211,88 & 288,12 & 288,12 & 83013,13 & 0,0053 & 0,0053 \\
\hline 12/01/2016 & 56000 & 54888,22 & 1111,78 & 1111,78 & 1236054,77 & 0,0199 & 0,0199 \\
\hline 13/01/2016 & 55900 & 55314,06 & 585,94 & 585,94 & 343325,68 & 0,0105 & 0,0105 \\
\hline 14/01/2016 & 55800 & 55314,06 & 485,94 & 485,94 & 236137,68 & 0,0087 & 0,0087 \\
\hline 15/01/2016 & 56300 & 54192,54 & 2107,46 & 2107,46 & 4441387,65 & 0,0374 & 0,0374 \\
\hline 18/01/2016 & 55500 & 54368,06 & 1131,94 & 1131,94 & 1281288,16 & 0,0204 & 0,0204 \\
\hline 19/01/2016 & 55000 & 55045,06 & $-45,06$ & 45,06 & 2030,40 & 0,0008 & $-0,0008$ \\
\hline 20/01/2016 & 55500 & 55471,32 & 28,68 & 28,68 & 822,54 & 0,0005 & 0,0005 \\
\hline 21/01/2016 & 55400 & 55471,32 & $-71,32$ & 71,32 & 5086,54 & 0,0013 & $-0,0013$ \\
\hline 22/01/2016 & 55250 & 54348,69 & 901,31 & 901,31 & 812359,72 & 0,0163 & 0,0163 \\
\hline 25/01/2016 & 54975 & 54524,39 & 450,61 & 450,61 & 203049,37 & 0,0082 & 0,0082 \\
\hline 26/01/2016 & 55875 & 55202,06 & 672,94 & 672,94 & 452848,24 & 0,0120 & 0,0120 \\
\hline 27/01/2016 & 58800 & 55628,74 & 3171,26 & 3171,26 & 10056889,99 & 0,0539 & 0,0539 \\
\hline 28/01/2016 & 58000 & 55628,74 & 2371,26 & 2371,26 & 5622873,99 & 0,0409 & 0,0409 \\
\hline 29/01/2016 & 58350 & 54505,00 & 3845 & 3845 & 14784025,00 & 0,0659 & 0,0659 \\
\hline Jumlah & 1112150 & 1098251,97 & 13898,03 & 4975,3 & 45683219,64 & 0,3994 & 0,2390 \\
\hline $\mathrm{n}$ & 10 & 10 & 10 & 10 & 10 & 10 & 10 \\
\hline \multirow[t]{2}{*}{ mean } & 111215 & 109825,20 & 1389,80 & 497,53 & 4568321,96 & 0,0399 & 0,0239 \\
\hline & & & MAD & MAE & MSE & MAPE & MPE \\
\hline
\end{tabular}

Sumber: data olahan Ms. Excel 2007

Selisih rata-rata antara harga saham aktual PT. Gudang Garam, Tbk. dan harga proyeksi menunjukan adanya underestimate antara hasil ramalan dengan nilai aktualnya. Hasil MAPE sebesar $4 \%$ menunjukan bahwa model relevan untuk digunakan dalam peramalan.

\section{KESIMPULAN DAN SARAN}

\section{Kesimpulan}

Berikut ini adalah kesimpulan dari penelitian:

Penelitian ini menemukan bahwa data harga saham PT. Gudang garam, Tbk. periode tahun 2010 - 2015 adalah data runtut waktu (time series) yang bersifat heteroskedastis sehingga harus menggunakan metode ARCH/GARCH.

Model yang paling tepat untuk meramalkan harga saham PT. Gudang Garam, Tbk. adalah variasi dari model ARCH/GARCH, yaitu model TGARCH (Treshold-GARCH).

Dari hasil estimasi didapat model yang paling fit, yaitu TGARCH $(1,1)$ yang kemudian digunakan untuk melakukan peramalan.

Hasil empiris dari penelitian ini menunjukan peramalan harga saham PT. Gudang Garam untuk periode 2 minggu (4 Januari 2016 15 Januari 2016), terbukti akurat dengan tingkat kesalahan peramalan rata-rata sebesar $4 \%$

\section{Saran}

Bagi para peneliti dan pihak akademisi yang mendalami dan melakukan penelitian pada bidang yang sama disarankan agar melakukan kajian pada indikator analisis teknikal yang lain mengingat banyaknya indikator analisis teknikal yang ada seperti VAR (Vector Autoregressive), dan CAPM (Capital Asset Pricing Model).

Bagi pihak investor dapat menggunakan TGARCH sebagai alat prediksi, atau melakukan kombinasi dari model peramalan sebelumnya, dalam melakukan investasi saham di PT. Gudang Garam, Tbk. 


\section{Keterbatasan Penelitian}

Penelitian ini hanya menggunakan data satu perusahaan saja (PT. Gudang Garam, Tbk. sehingga hasilnya tidak bisa digeneralisasi pada perusahaan industri rokok lainnya yang sudah go public di BEI. Oleh karena itu, model penelitian ini perlu direplikasi dengan menggunakan data dari perusahaan-perusahaan lain yang berbeda jenis sektor, sehingga dapat diperoleh informasi yang dapat mendukung hasil penelitian ini.

\section{DAFTAR PUSTAKA}

Ajija, S.R., Sari, D.W., Setiano, R.H., \& Primanti, M.R. (2011). Cara Cerdas Menguasai EViews. Jakarta: Salemba Empat.

Apa Pengertian Ahli (2014). Pengertian Pasar Modal. Diakses 10 Oktober 2015. http:// www.apapengertianahli.com/2014/09/ pengertian-pasar-modal.html

Aritonang, L.R. (2002). Peramalan Bisnis. Jakarta: Ghalia Indonesia.

Eliyawati, W.Y., Hidayat, R.R, \& Azizah, D.F. (2014). Penerapan Model GARCH (GeneralizedAutoregressive Conditional Heteroscedaticity) Untuk Menguji Pasar Modal Efisien di Indonesia. Jurnal. Universitas Brawijaya, Malang.

Fitriani, D. A. (2009). Analisis Day of The Week Effect Terhadap Imbal Hasil IHSG. Skripsi. Universitas Indonesia, Depok.

Gozali, A. (2012). Analisis Teknikal. Diakses 1 Oktober 2015. http://aldigozali. com/?page $\mathrm{id}=284$

Gujarati, D. N. (2003). Basic Econometrics (fourth edition). McGraw-Hill: New York

Ilmu Akuntansi (2012). Pengertian Saham dan Jenis Saham. Diakses 1 Oktober 2015. http://ilmuakuntansi.web.id/pengertiansaham-dan-jenis-saham/

Janah, R. S. (2010). Analisis Volatilitas Return Harga Minyak Kelapa Sawit Di Pasar
Internasional. Skripsi. Universitas Diponegoro, Semarang.

Lilipaly, G.S., Hatidja, D., \& Kekenusa, J.S. (2014). Prediksi Harga Saham PT. BRI, Tbk. Menggunakan Metode ARIMA. Jurnal. UNSRAT, Manado.

Prasetyo, A.S \& Rahardjo, S. (2013). Peramalan Data Nilai Ekspor Non Migas Indonesia Ke Wilayah ASEAN Menggunakan Model EGARCH. Jurnal. Universitas Negeri Malang, Malang.

Ramadhan, B.A. (2014). Analisis Perbandingan Metode ARIMA dan Metode GARCH Untuk Memprediksi Harga Saham. Jurnal. Universitas Telkom, Bandung. menggunakan-model-arima-2/

Sadeq, A. (2008). Analisis Prediksi Indeks Harga Saham Gabungan Dengan Metode ARIMA. Tesis. Universitas Diponegoro, Semarang.

Sumaryanto (2009). Analisis Volatilitas Harga Eceran Beberapa Komoditas Pangan Utama Dengan Model ARCH/GARCH. Jurnal Agro Ekonomi. Pusat Analisis Sosial Ekonomi dan Kebijakan Pertanian.

Uji Statistik (2014). Jarque Bera. Diakses 16 Januari 2016. http://www.statistikian. com/2014/08/jarque-bera.html

Widarjono, A. (2007). EKONOMETRIKA Teori dan Aplikasi Untuk Ekonomi dan Bisnis (Edisi 2). Yogyakarta: EKONISIA.

Widasari, L.P \& Wahyuningsih, N. (2012). Aplikasi Model ARCH-GARCH Dalam Peramalan Tingkat Inflasi. Jurnal. Institut Teknologi Sepuluh Nopember, Surabaya.

Winarno, W.W. (2015). Analisis Ekonometrika dan Statistika dengan EViews (Edisi 4). Yogyakarta: UPP STIM YKPN.

Yani, A. (2004). Analisis Teknikal Harga Saham Dengan Metode ARIMA. Tesis. Universitas Diponegoro, Semarang. 